\title{
Peningkatan Kemampuan Berjalan dan Energy Expenditure pada Palsi Serebral yang Menjalani Latihan Penguatan dengan Metode Periodisasi
}

\author{
Dian Marta Sari, ${ }^{1}$ Marietta Shanti, ${ }^{1}$ Dany Hilmanto ${ }^{2}$ \\ ${ }^{1}$ Departemen Ilmu Kedokteran Fisik dan Rehabilitasi, Fakultas Kedokteran Universitas Padjadjaran/Rumah Sakit \\ Dr. Hasan Sadikin Bandung, ${ }^{2}$ Departemen Ilmu Kesehatan Anak, Fakultas Kedokteran Universitas Padjadjaran/ \\ Rumah Sakit Dr. Hasan Sadikin Bandung
}

\begin{abstract}
Abstrak
Palsi serebral (PS) pada anak dapat menyebabkan gangguan spastisitas dan kelemahan otot sehingga kemampuan mobilisasinya menjadi terbatas. Latihan penguatan pada anak PS diharapkan mampu memperbaiki kemampuan mobilisasi. Tujuan penelitian ini adalah menilai pengaruh latihan penguatan dengan periodisasi pada anak PS spastik diplegi terhadap kemampuan berjalan dan energy expenditure. Subjek penelitian ini diambil bersekolah di Yayasan Pembinaan Anak Cacat (YPAC), Sekolah Luar Biasa (SLB), dan sekolah inklusi di Bandung dan sekitarnya periode Oktober 2011-Juni 2012. Penelitian ini menggunakan uji acak terkontrol. Dua puluh dua anak (usia 7-14 tahun) dengan PS spastik diplegi, Gross Motor Function Classification System I-III dibagi menjadi kelompok intervensi dan kelompok kontrol secara random. Kelompok intervensi mendapat latihan penguatan duduk berdiri dengan beban menggunakan metode periodisasi, 3 kali/minggu selama 7 minggu yang dilakukan di rumah masing-masing. Parameter yang dinilai adalah kemampuan berjalan (stride length, cadence, dan kecepatan berjalan) dan Physiological Cost Index (PCI) yang diukur saat sebelum dan sesudah latihan selama 7 minggu. Setelah latihan selama 7 minggu menunjukkan perubahan stride length $(13,99 \%$ vs $-2,46 \%$; p:0,006), cadence (12,27\% vs -7,92\%; p:0,007), kecepatan berjalan (12,65\% vs -0,64\%; p:0,028), dan PCI (24,23\% vs -25,66\%; $\mathrm{p}<0,001$ ) pada kelompok intervensi dibanding dengan kelompok kontrol. Latihan penguatan duduk berdiri dengan beban dapat meningkatkan kemampuan berjalan (stride length, cadence, serta kecepatan berjalan) dan menurunkan energy expenditure pada anak PS spastik diplegi. [MKB. 2017;49(1):48-54]
\end{abstract}

Kata kunci: Energy expenditure, kemampuan berjalan, latihan penguatan, palsi serebral

\section{Effectiveness of Periodization Strengthening Exercise on Walking Ability and Energy Expenditure in Cerebral Palsy}

\begin{abstract}
Children with cerebral palsy (CP) may experience spasticity and muscle weakness. All impaired muscle functions limit the mobilization ability in children with CP. Strength training for these children is expected to improve their mobility. The purpose of this study was to investigate the effectiveness of a functional strengthening program with periodization for children with $\mathrm{CP}$ on walking ability and energy expenditure. The subjects of this study were taken at the YPAC, Special School (SLB), and inclusion schools in Bandung and surrounding areas from October 2011 to June 2012. This study used randomized controlled trial design. Twenty-two children (aged: 7-14 y.o.) with spastic diplegia CP and level I-III Gross Motor Function Classification System were evenly stratified and randomly allocated into either experimental or control group. The experimental group underwent home-based loadedsit-to-stand strengthening exercise ( 3 times/week, 7 weeks). The main outcome measures were walking ability (stride length, cadence, and walking speed) and Physiological Cost Index (PCI), conducted at the beginning and end of the 7-week study. After 7-week of exercise, the results showed changes on stride length $(13.99 \%$ vs $-2.46 \%$; p:0.006), cadence (12.27\% vs -7.92\%; p:0.007), walking speed (12.65\% vs -0.64\%; p:0.028), flexibility (6.80\% vs $2.50 \%$; p:0.221), and PCI (24.23\% vs $-25.66 \%$; p<0.001) between the experimental group and the control group. After the loaded STS exercise, children with spastic diplegia improve their walking ability (stride length, cadence, and walking speed) and decrease their energy expenditure. [MKB. 2017;49(1):48-54]
\end{abstract}

Key words: Cerebral palsy, energy expenditure, strengthening exercise, walking ability

Korespondensi: Dian Marta Sari, dr., Sp KFR., M.Kes, Departemen Ilmu Kedokteran Fisik dan Rehabilitasi, Fakultas Kedokteran Universitas Padjadjaran/Rumah Sakit Dr. Hasan Sadikin Bandung, Jalan Pasteur No. 38 Bandung, mobile: 081221812279, e-mail: dr.dianrw@gmail.com 


\section{Pendahuluan}

Palsi serebral (PS) ialah merupakan penyebab ketidakmampuan fungsional paling banyak pada masa anak-anak. Pada penderita PS terdapat kelemahan otot, gerakan involunter atau inkoordinasi. ${ }^{1,2}$ Insidensi PS adalah 2-2,5/1.000 kelahiran hidup. ${ }^{3,4}$ Gangguan fungsi otot ini akan menyebabkan disfungsi gerak dan membatasi aktivitas kehidupan sehari-hari. Anak PS tipe spastik mampu berjalan mandiri, akan tetapi kemampuan mereka berjalan tidak lebih baik daripada teman sebayanya yang normal dan bertambah buruk sesuai dengan bertambahnya usia sehingga kemampuan untuk berjalan dapat menurun. ${ }^{1}$ Kemampuan berjalan bertambah baik apabila seseorang memiliki kekuatan otot, keseimbangan, dan faktor-faktor lainnya. ${ }^{5}$

Berbagai penelitian menunjukkan kekuatan otot itu berhubungan langsung dengan fungsi motor sehingga mampu memperbaiki stride length, cadence, serta kecepatan berjalan dan menurunkan energy expenditure dengan cara serta hasil yang berbeda-beda. ${ }^{1,6}$ Hasil penelitian sebelumnya belum memuaskan karena dalam pemberian latihan penguatan masih terdapat variabilitas karakteristik latihan yang tinggi, seperti tipe latihan (misal latihan isometrik atau isotonik), intensitas latihan (misal beban yang diberikan saat latihan), frekuensi latihan (misal 2 kali per minggu atau 3 kali per minggu), dan periode latihan (bervariasi dari 6 hingga 12 minggu). Latihan penguatan akan memberikan hasil jika peresepan latihan ini dibuat secara individual dan yang sesuai tujuan meningkatkan kekuatan otot itu, yaitu dengan menentukan intensitas latihan. ${ }^{5,6}$ Salah satu konsep dari teori latihan adalah periodisasi. Periodisasi bertujuan menstimulasi adaptasi fisiologis dan psikologis (preparatory phase), meningkatkan kapasitas performa (competitive phase), lalu dilanjutkan dengan transition phase yang bertujuan relaksasi dan mempersiapkan tahap berikutnya. ${ }^{5}$

Tujuan penelitian ini adalah mengetahui pengaruh latihan penguatan duduk berdiri dengan beban menggunakan metode periodisasi terhadap kemampuan berjalan dan juga energy expenditure pada PS. Cara ini lebih mudah dan murah karena dapat dilakukan di rumah.

\section{Metode}

Metode penelitian adalah studi intervensional dengan rancangan acak terkontrol (sebelum dan sesudah intervensi). Pelaksanaan dilakukan dalam kurun waktu Oktober 2011-Juni 2012, setelah mendapat persetujuan etik dari Komite Etik Penelitian Kesehatan Fakultas Kedokteran Universitas Padjadjaran.

Subjek penelitian ini diambil dengan metode total sampling yang bersekolah di Yayasan Pembinaan Anak Cacat (YPAC), Sekolah Luar Biasa (SLB), dan sekolah inklusi di Bandung dan sekitarnya. Kriteria penerimaan pada penelitian ini adalah penderita PS spastik diplegi dengan Gross Motor Function Classification System (GMFCS) tingkat I-III, usia 7-14 tahun, mampu berdiri dari posisi duduk secara independen dan mempertahankan posisi berdiri selama lebih dari 5 detik tanpa jatuh, mampu memahami instruksi lisan, tidak ada keterbatasan lingkup gerak sendi pasif anggota gerak bawah, dan tidak mendapat latihan penguatan selama 3 bulan terakhir. Kriteria penolakannya adalah intervensi ortopedi (rizotomi dorsal atau suntik botulinum toksin pada anggota gerak bawah) dalam 6 bulan terakhir, masalah ortopedik atau kondisi medik yang menghalangi untuk berpartisipasi dalam penelitian. Subjek yang tidak melakukan latihan 4 kali berturut-turut dinyatakan drop out dari penelitian ini.

Semua subjek telah mendapat penjelasan mengenai program penelitian. Subjek yang bersedia mengikuti program penelitian telah menandatangani surat persetujuan untuk dapat mengikuti penelitian, lalu dilakukan anamnesis dan pemeriksaan fisis oleh peneliti. Data dasar diambil sebelum latihan dan sesudah latihan selama tujuh minggu. Data dasar yang berupa stride length, cadence, dan kecepatan berjalan diambil dengan cara subjek berjalan di atas kain blacu sepanjang 10 meter yang terlebih dahulu kakinya menginjak tinta di bak. Kecepatan berjalan diukur menggunakan stopwatch merk Diamond. Energy expenditure diukur dengan cara menghitung selisih denyut jantung subjek saat istirahat dan saat berjalan dibagi dengan kecepatan berjalan yang dikenal dengan istilah Physiological Cost Index (PCI). Denyut jantung diukur menggunakan polar merk Omron. Subjek diminta untuk berjalan selama 8 menit dengan pola angka 8 yang dibentuk dari 2 lingkaran dengan diameter 3,2 meter pada karton duplek dengan ukuran $3,5 \times 7$ meter. ${ }^{1,7}$

Subjek dibagi menjadi dua kelompok, yaitu kelompok intervensi yang mendapat latihan penguatan duduk berdiri dengan beban memakai metode periodisasi dan kelompok kontrol yang mendapat latihan lingkup gerak sendi pasif.

Latihan dilakukan di rumah sebanyak 3 set tiap latihan, 3 kali per minggu selama 7 
minggu. Tes beban maksimal (10 repetisi maksimal) dilakukan pada kelompok intervensi dengan beban yang diberikan untuk tes $10 \mathrm{RM}$ diperkirakan 30\% dari berat badan subjek. Beban dimasukkan ke dalam kantong jaket yang dikenakan oleh subjek. Penentuan beban latihan (tes $10 \mathrm{RM}$ ) ini dilakukan pada akhir minggu pertama dan keempat, lalu ditentukan dosis latihan. Latihan dengan beban sebesar 40\% dari 10 RM dimulai pada minggu kedua, kemudian dinaikkan menjadi $50 \%$ dan $60 \%$ pada minggu ketiga dan keempat. Beban yang diberikan pada minggu kelima, keenam, dan ketujuh sebesar 50\%, 60\%, dan 70\% dari 10 RM yang diukur pada minggu keempat sehingga selama tujuh minggu latihan terdapat fase unloading dan fase overloading menggunakan metode periodisasi. ${ }^{5}$ Sebelum latihan dimulai dilakukan pemanasan, kemudian setelah latihan dilakukan pendinginan dengan gerakan-gerakan berupa peregangan otot aduktor panggul, plantar fleksor pergelangan kaki, hamstring, dan ekstensor lumbal. Caregiver diminta untuk mengisi buku harian latihan setelah melakukan latihan.

Analisis data menggunakan uji Shapiro Wilks untuk uji normalitas data numerik dengan total sampel minimal kurang dari 50. Untuk menguji pengaruh latihan terhadap kemampuan berjalan, dan energy expenditure bila dibandingkan dengan kelompok kontrol antara sebelum dan sesudah latihan, dilakukanlah analisis statistik dengan paired $T$ test bila data terdistribusi normal dan uji Wilcoxon bila data tidak terdistribusi normal.

\section{Hasil}

Subjek penelitian yang telah memenuhi kriteria penerimaan, yaitu sebanyak 23 orang, terdapat seorang drop out sehingga jumlah subjek yang selesai melakukan latihan selama 7 minggu sebanyak 22 orang dibagi menjadi 2 kelompok dengan tiap-tiap kelompok sebanyak 11 orang.

Data karakteristik penderita PS spastik diplegi yang meliputi jenis kelamin, usia, berat badan, tinggi badan, dan GMFCS antara kedua kelompok tidak terdapat perbedaan bermakna sehingga kedua kelompok layak untuk dibandingkan.

Nilai variabel yang menunjukkan kemampuan berjalan (stride length, cadence, dan kecepatan berjalan) dan energy expenditure (PCI) pada kelompok intervensi dan juga kontrol sebelum dilakukan latihan tidak terdapat perbedaan bermakna $(p>0,05)$ sehingga layak dibandingkan (Tabel 1). Analisis statistik perubahan nilai variabel yang menentukan kemampuan berjalan pada kelompok intervensi (Tabel 2), yaitu peningkatan stride length dan cadence, serta

Tabel 1 Nilai Stride Length, Cadence, Kecepatan Berjalan, dan PCI pada Kelompok Intervensi dan Kontrol Sebelum Latihan

\begin{tabular}{|c|c|c|c|c|}
\hline \multirow{2}{*}{ Variabel } & \multicolumn{2}{|c|}{ Kelompok } & \multirow{2}{*}{$\begin{array}{l}\text { Nilai t } \\
\text { atau Z }\end{array}$} & \multirow{2}{*}{ Nilai $p$} \\
\hline & Intervensi $(\mathrm{n}=11)$ & Kontrol $(n=11)$ & & \\
\hline \multicolumn{5}{|l|}{$\begin{array}{l}\text { 1. Kemampuan berjalan } \\
\text { a. Stride length }(\mathrm{cm})\end{array}$} \\
\hline Rata-rata (SD) & $68,45(16,29)$ & $67,73(21,57)$ & $0,089^{\dagger}$ & 0,930 \\
\hline Rentang & $46-92$ & $24-104$ & & \\
\hline \multicolumn{5}{|c|}{ b. Cadence (kali/menit) } \\
\hline Rata-rata (SD) & $92,09(23,33)$ & $96,45(58,61)$ & $0,581^{\dagger \dagger}$ & 0,554 \\
\hline $\begin{array}{l}\text { Median } \\
\text { Rentang }\end{array}$ & 98,00 & 92,00 & & \\
\hline Rentang & $42-125$ & $38-257$ & & \\
\hline \multicolumn{5}{|c|}{ c. Kecepatan berjalan (m/detik) } \\
\hline \multicolumn{5}{|c|}{ Rata-rata (SD) } \\
\hline Median & $0,55(0,21)$ & $0,51(0,36)$ & $0,920^{\dagger \dagger}$ & 0,357 \\
\hline Rentang & 0,56 & 0,50 & & \\
\hline \multicolumn{5}{|l|}{ 2. PCI (denyut/meter) } \\
\hline Rata-rata (SD) & $1,34(1,29)$ & $1,36(1,20)$ & $0,066^{\dagger \dagger}$ & 0,948 \\
\hline Median & 0,87 & 0,94 & & \\
\hline Rentang & $0,46-5,02$ & $0,53-4,46$ & & \\
\hline
\end{tabular}

Keterangan: ${ }^{\dagger}$ ) berdasar atas uji-t; ${ }^{+\dagger}$ ) berdasar atas uji Mann-Whitney 
Tabel 2 Perubahan Nilai Stride Length, Cadence, Kecepatan Berjalan, serta PCI Sebelum dengan Sesudah Latihan pada Kelompok Intervensi

\begin{tabular}{|c|c|c|c|c|}
\hline \multirow{2}{*}{ Variabel } & \multicolumn{2}{|c|}{ Kelompok Intervensi } & \multirow{2}{*}{$\mathbf{z}_{\mathrm{w}}$} & \multirow{2}{*}{ Nilai p } \\
\hline & Sebelum & Sesudah & & \\
\hline \multirow{2}{*}{\multicolumn{5}{|c|}{$\begin{array}{l}\text { 1. Kemampuan berjalan } \\
\text { a. Stride length }\end{array}$}} \\
\hline & & & & \\
\hline Rata-rata (SD) & $68,45(16,30)$ & $76,91(17,56)$ & \multirow{3}{*}{2,401} & \multirow{3}{*}{0,008} \\
\hline Median & 71,00 & 72,00 & & \\
\hline Rentang & $46-92$ & $47-104$ & & \\
\hline \multicolumn{5}{|l|}{ b. Cadence (kali/menit) } \\
\hline Rata-rata (SD) & $92,09(23,33)$ & $102,18(24,98)$ & \multirow{3}{*}{2,357} & \multirow{3}{*}{0,009} \\
\hline Median & 98,00 & 103,00 & & \\
\hline Rentang & $42-125$ & $54-146$ & & \\
\hline \multicolumn{5}{|c|}{ c. Kecepatan berjalan (m/detik) } \\
\hline Rata-rata (SD) & $0,55(0,21)$ & $0,59(0,20)$ & \multirow{3}{*}{1,380} & \multirow{3}{*}{0,084} \\
\hline Median & 0,56 & 0,71 & & \\
\hline Rentang & $0,22-0,83$ & $0,26-0,83$ & & \\
\hline \multicolumn{5}{|l|}{ 2. PCI (denyut/meter) } \\
\hline Rata-rata (SD) & $1,34(1,29)$ & $0,98(0,95)$ & \multirow{3}{*}{2,803} & \multirow{3}{*}{0,003} \\
\hline Median & 0,87 & 0,63 & & \\
\hline Rentang & $0,46-5,02$ & $0,34-3,69$ & & \\
\hline
\end{tabular}

Keterangan: $\mathrm{Zw}=$ uji Wilcoxon

penurunan energy expenditure (PCI) sebelum dan sesudah latihan dengan menggunakan uji Wilcoxon didapatkan perubahan yang bermakna $(\mathrm{p}<0,05)$. Variabel kecepatan berjalan pada kelompok intervensi sebelum dan juga sesudah latihan tidak terdapat peningkatan bermakna $(\mathrm{p}>0,05)$.

Perubahan nilai variabel yang menentukan

Tabel 3 Perubahan Nilai Stride Length, Cadence, Kecepatan Berjalan, serta PCI Sebelum dengan Sesudah Latihan pada Kelompok Kontrol

\begin{tabular}{|c|c|c|c|c|}
\hline \multirow{2}{*}{ Variabel } & \multicolumn{2}{|c|}{ Kelompok Kontrol } & \multirow[b]{2}{*}{$\mathbf{Z}_{\mathrm{w}}$} & \multirow{2}{*}{ Nilai $\mathrm{p}$} \\
\hline & Sebelum & Sesudah & & \\
\hline \multicolumn{5}{|l|}{$\begin{array}{l}\text { 1. Kemampuan berjalan } \\
\text { a. Stride length }(\mathrm{cm})\end{array}$} \\
\hline Rata-rata (SD) & $67,73(21,57)$ & $66,18(21,21)$ & 1,158 & 0,247 \\
\hline Median & 65,00 & 66,00 & & \\
\hline Rentang & $24-104$ & $21-97$ & & \\
\hline \multicolumn{5}{|l|}{ b. Cadence (kali/menit) } \\
\hline Rata-rata (SD) & $96,45(58,61)$ & $84,27(42,04)$ & 1,557 & 0,119 \\
\hline Median & 92,00 & 86,00 & & \\
\hline Rentang & $38-257$ & $37-180$ & & \\
\hline \multicolumn{5}{|c|}{ c. Kecepatan berjalan (m/detik) } \\
\hline Rata-rata (SD) & $0,51(0,36)$ & $0,47(0,29)$ & & \\
\hline Median & 0,50 & 0,40 & 0,981 & 0,326 \\
\hline Rentang & $0,14-1,43$ & $0,16-1,11$ & & \\
\hline \multicolumn{5}{|l|}{ 2. PCI (denyut/meter) } \\
\hline Rata-rata (SD) & $1,36(1,20)$ & $1,50(0,97)$ & & \\
\hline Median & 0,94 & 1,09 & 1,824 & 0,068 \\
\hline Rentang & $0,53-4,46$ & $0,66-3,53$ & & \\
\hline
\end{tabular}

Keterangan: Zw = uji Wilcoxon 
Tabel 4 Persentase Perubahan dari Berbagai Variabel yang Diukur antara Kelompok Intervensi dan Kelompok Kontrol

\begin{tabular}{lcccc}
\hline \multirow{2}{*}{ Rata-rata \% Perubahan } & \multicolumn{2}{c}{ Kelompok } & & Nilai p \\
\cline { 2 - 3 } & $\begin{array}{c}\text { Intervensi } \\
\text { (n=11) }\end{array}$ & $\begin{array}{c}\text { Kontrol } \\
(\mathbf{n = 1 1 )}\end{array}$ & $\mathbf{z}_{\mathrm{Mw}}$ & \\
\hline $\begin{array}{l}\text { 1. Kemampuan berjalan } \\
\text { a. Stride length (cm) }\end{array}$ & 13,99 & $-2,46$ & 2,528 & 0,006 \\
b. Cadence (kali/menit) & 12,27 & $-7,92$ & 2,462 & 0,007 \\
c. Kecepatan berjalan (m/detik) & 12,65 & $-0,64$ & 1,910 & 0,028 \\
2. PCI (denyut/meter) & 24,23 & $-25,66$ & 3,447 & $<0,001$ \\
\hline
\end{tabular}

Keterangan: persentase perubahan $=100 *$ sesudah latihan - sebelum latihan sebelum latihan

$\mathrm{Z}_{\mathrm{MW}}=$ uji Mann Whitney

kemampuan berjalan (stride length, cadence, dan kecepatan berjalan) dan energy expenditure (PCI) sebelum dan sesudah latihan pada kelompok kontrol dengan menggunakan uji Wilcoxon tidak terdapat perbedaan yang bermakna (Tabel 3).

Persentase perubahan nilai variabel yang sudah menunjukkan kemampuan berjalan (stride length, cadence, dan kecepatan berjalan) serta energy expenditure (PCI) sebelum dan sesudah latihan pada kedua kelompok menunjukkan perbedaan yang bermakna ( $<<0,05$; Tabel 4$)$.

\section{Pembahasan}

Peningkatan pada stride length yang bermakna setelah latihan bila dibanding dengan sebelum latihan penguatan duduk berdiri dengan beban pada kelompok intervensi $(\mathrm{p}<0,05)$ ini sesuai dengan penelitian yang dilakukan Lee $\mathrm{dkk}^{8}{ }^{8}$ yang menunjukkan setelah latihan penguatan otot kuadrisep terdapat peningkatan stride length yang bermakna. Kekuatan otot kuadrisep yang meningkat akan menghasilkan gaya yang lebih besar. Hal ini mengakibatkan lutut mampu untuk ekstensi maksimal dan menurunkan sudut fleksi lutut saat fase terminal swing/deselerasi waktu berjalan sehingga kaki dapat memposisikan secara baik sesaat sebelum menyentuh lantai dan memberikan hasil peningkatan stride length. Peningkatan kekuatan otot ini disebabkan oleh peningkatan fungsi dan hipertrofi miofibril sesudah dilakukan latihan. ${ }^{9}$ Hal ini juga sesuai dengan penelitian yang dilakukan Ross dan Engsberg $^{10}$ dan juga penelitian oleh Eek dan Beckung $^{11}$ memperlihatkan hubungan antara kekuatan otot plantar fleksor dan kemampuan berjalan anak palsi serebral. Otot plantar fleksor diperlukan pada fase stance dan fase push off saat berjalan. Lima puluh persen gaya yang dihasilkan oleh otot plantar fleksor ini untuk memberikan dorongan saat berjalan sehingga diperoleh stride length yang sesuai. Penelitian yang dilakukan saat ini dan penelitian-penelitian sebelumnya memberikan hasil yang sama, yaitu peningkatan stride length, meskipun jenis latihan yang diberikan berbeda. Hasil penelitian ini juga menunjukkan persentase peningkatan stride length sebelum dengan sesudah latihan pada kelompok intervensi dan kelompok kontrol terdapat perbedaan yang bermakna.

Peningkatan cadence yang bermakna pada kelompok intervensi sesudah latihan dibanding dengan sebelum latihan penguatan duduk berdiri dengan beban ini telah sesuai dengan penelitian Ross dan Engsberg ${ }^{10}$ serta Mockford dan Caulton. ${ }^{12}$ Ross dan Engsberg ${ }^{10}$ yang meneliti hubungan antara kekuatan otot anggota gerak bawah keseluruhan dan kemampuan berjalan, salah satunya adalah cadence menunjukkan hubungan sedang antara kekuatan otot dan cadence. Penelitian ini menunjukkan persentase peningkatan cadence sebelum dengan sesudah latihan pada kelompok intervensi dan kelompok kontrol terdapat perbedaan yang bermakna.

Hasil penelitian ini menunjukkan peningkatan kecepatan berjalan yang tidak bermakna pada kelompok intervensi sesudah latihan apabila dibanding dengan sebelum latihan penguatan duduk berdiri dengan beban, meskipun terdapat peningkatan kecepatan berjalan sesudah latihan pada kelompok intervensi. Hal ini sesuai dengan penelitian Liao dkk., ${ }^{1}$ Engsberg dkk., ${ }^{13}$ serta Eek dkk. ${ }^{14}$ bahwa tidak terjadi peningkatan kecepatan berjalan yang bermakna, akan tetapi terdapat peningkatan kecepatan berjalan sesudah latihan 
penguatan. Hal ini disebabkan oleh subjek pada penelitian yang menderita PS ringan, yaitu GMFCS I-II dan kecepatan berjalan sebelum latihan berada dalam rentang normal berdasar atas usia. Penelitian yang dilakukan saat ini menggunakan subjek penelitian dengan GMFCS I-III dan kecepatan berjalan sebelum latihan berada di bawah rentang normal berdasar usia. Hasil pada kelompok kontrol juga menunjukkan tidak terdapat peningkatan kecepatan berjalan yang bermakna antara sebelum dan sesudah latihan.

Oleh karena tidak ada perubahan kecepatan berjalan antara sebelum dan sesudah latihan, baik pada kelompok intervensi maupun kelompok kontrol, maka untuk melihat besar pengaruh latihan penguatan duduk berdiri dengan beban terhadap kecepatan berjalan, dihitung perbandingan persentase peningkatan kecepatan berjalan sebelum dan sesudah latihan antara kelompok intervensi dan kelompok kontrol yang menunjukkan hasil bermakna. Hal ini sesuai dengan penelitian oleh Rossdan dan Engsberg ${ }^{10}$ yang menunjukkan kekuatan pada ekstensor lutut anak PS berhubungan lurus dengan kecepatan berjalan. Anak dengan ekstensor lutut yang kuat mampu melakukan motorik kasar yang lebih baik, berjalan lebih cepat, dan posisi crouch berkurang.

Penurunan PCI pada kelompok intervensi sesudah latihan apabila dibandingkan dengan sebelum latihan penguatan duduk berdiri dengan beban dan persentase penurunan PCI sebelum dan sesudah latihan pada kelompok intervensi dibanding dengan kelompok kontrol menunjukkan hasil yang bermakna. Hal ini sesuai dengan penelitian Liao dkk. ${ }^{1}$ serta Mockford dan Caulton. ${ }^{12}$ Kekuatan pada ekstensor lutut anak PS berhubungan terbalik dengan PCI. Anak dengan ekstensor lutut yang kuat mampu melakukan motorik kasar yang lebih baik, berjalan lebih cepat, posisi crouch berkurang, dan juga menurunkan energy expenditure saat berjalan. Peningkatan kecepatan berjalan yang diikuti dengan peningkatan stride length akan meningkatkan efisiensi energi selama berjalan. Latihan penguatan anggota gerak bawah akan meningkatkan kekuatan otot anggota gerak bawah yang sebagian besar digunakan untuk kemampuan berjalan dan dapat meningkatkan kapasitas aerobik. Dengan demikian pemakaian energi saat berjalan menjadi berkurang dan mengurangi kelelahan pada saat berjalan seiring dengan menguatnya otot setelah latihan.

Keterbatasan penelitian ini, penggunaan kain blacu 10 meteryang diletakkan di atas permukaan lantai dan bagian tepi kain direkatkan pada lantai menggunakan plester, sesudah terlebih dahulu kedua kaki subjek menginjak tinta di bak untuk analisis kemampuan berjalan. Hal ini mengakibatkan perubahan koefisien gesek kain dengan lantai dan kaki yang terkena tinta dengan kain sehingga saat berjalan diperkirakan subjek harus menjaga keseimbangan agar tidak jatuh dengan memperlambat berjalannya. Pada saat berjalan terdapat gaya-gaya yang bekerja, yaitu gaya gravitasi/center of gravity (pada orang yang berjalan) maupun gaya gesek (pada lantainya). Proses berjalan (proses dinamik) pada kondisi lantai normal mengakibatkan perubahan center of gravity tubuh sehingga subjek berupaya mempertahankan keseimbangannya agar tidak jatuh. Terdapat perubahan koefisien gesek yang diperkirakan, dapat menyebabkan subjek akan semakin kesulitan menjaga keseimbangan sehingga kecepatan berjalan yang terjadi tidak turut memperlihatkan kecepatan berjalan yang sesungguhnya.

Simpulan, latihan penguatan duduk berdiri dengan beban menggunakan metode periodisasi selama tujuh minggu mampu meningkatkan kemampuan berjalan (stride length, cadence, dan kecepatan berjalan) dan menurunkan energy expenditure pada anak PS.

\section{Daftar Pustaka}

1. Liao HF, Liu YC, Liu WY, Lin YT. Effectiveness of loaded sit-to-stand resistance exercise for children with mild spastic diplegia: a randomized clinical trial. Arch Phys Med Rehabil. 2007;88(1):25-31.

2. Shankaran S. Diagnosis, treatment, and prevention of near-term/term infants. Clin Obstet Gynecol. 2008;51(4):816-28.

3. Odding E, Roebroeck ME, Stam HJ. The epidemiology of cerebral palsy: incidence, impairment and risk factors. Disabil Rehabil. 2006;28(4):183-91.

4. Berker N, Yalcin $\mathrm{S}$. The help guide to cerebral palsy. Edisi ke-2. Turkey: Global-HELP organization; 2010.

5. Bompa TO Haff G. Periodization. theory and methodology of training. Edisi ke-5. USA: Human Kinetics; 2009.

6. Behm DG, Faigenbaum AD, Falk B, Klentrou P. Canadian society for exercise physiology position paper: resistance training in children and adolescents. Appl Physiol Nutr Metab. 2008;33(3):547-61.

7. Raja K, Joseph B, Benjamin S, Minocha 
V, Rana B. Physiological cost index in cerebral palsy: Its role in evaluating the efficiency of ambulation. J Pediatr Orthop. 2007;27(2):130-6.

8. Lee JH, Sung IY, Yoo JY. Therapeutic effects of strengthening exercise on gait function of cerebral palsy. Disabil Rehabil. 2008;30(19):1439-44.

9. Becker BE. 46th Walter J. Zeiter lecture, exercise is rehabilitation medicine: our history and future. PMR. 2015;7(4):345-3.

10. Ross SA, Engsberg JR. Relationship between spasticity, strength, gait, and the GMFM-66 in persons with spastic diplegia cerebral palsy. Arch Phys Med Rehabil. 2007;88(9):111420.
11. Eek MN, Beckung E. Walking ability is related muscle strength in children with cerebral palsy. Gait Posture. 2008;28(3):366-71.

12. Mockford M, Caulton JM Systematic review of progressive strength training in children and adolescents with cerebral palsy who are ambulatory. Pediatr Phys Ther. 2008;20(4):318-33.

13. Engsberg JR, Ross SA, Collins DR.. Increasing ankle strength to improve gait and function in children with cerebral palsy: a pilot study. Pediatr Phys Ther. 2006;18(4):266-75.

14. Eek MN TR, Zügner R, Alkema K, Beckung E. Muscle strength training to improve gait function in children with cerebral palsy. Dev Med Child Neurol. 2008;50(10):759-64. 